\title{
Influence of Phosphorus Fertilizer on "Ware" Potato Production in Acid Soils in Kenya
}

\author{
Evans Mutange Akoto ${ }^{1}$, Caleb O. Othieno ${ }^{2} \&$ Julius O. Ochuodho ${ }^{3}$ \\ ${ }^{1}$ Ministry of Agriculture, Livestock Development, Fisheries \& Cooperatives, Nairobi, Kenya \\ ${ }^{2}$ Department of Soil Science, University of Eldoret, Kenya \\ ${ }^{3}$ Department of Crops, Seed and Horticultural sciences, University of Eldoret, Kenya \\ Correspondence: Evans Mutange, Ministry of Agriculture, Livestock Development, Fisheries and Cooperatives, \\ Nairobi, Kenya. Tel: 254-718-796-253. E-mail: akotomutange@ gmail.com
}

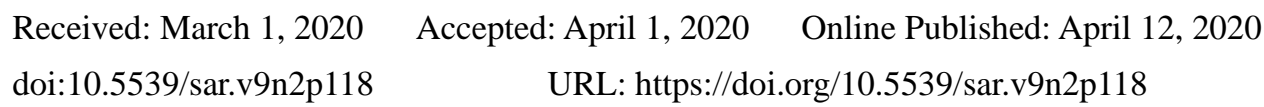

\begin{abstract}
One of the major challenges facing potato (Solanum Tuberosum L) production in Kenya is low and declining yield. This trend is caused by several factors which include low quality and quantity of seed, climate change, inadequate extension services, pests and diseases and more importantly low and declining soil fertility, particularly phosphorus (KEPHIS, 2016 and Karanja et al., 2014). Unfortunately, the current phosphorus fertilizer rate recommendation available for "ware" potato production in Kenya is "blanket" or general (90 kg phosphorus $\mathrm{ha}^{-1}$ ) and has not been updated for a long time to address the declining soil fertility. This prevents proper utilization of phosphorus fertilizers in achieving optimal production of "ware" potatoes. Therefore, this study investigated influence of different rates of phosphorus (TSP) fertilizer on "ware" potato yield and quality in three acidic $(\mathrm{pH} \leq 5.8)$ test sites: Lari, Ainabkoi and Saboti sub Counties. Two varieties, Unica and Shangi, were tested. The field experiment was a split plot arrangement in Randomised Complete Block Design (RCBD) with six treatments ( $0 \mathrm{~N} \& 0 \mathrm{P}), 0,30,60,90$ and $120 \mathrm{~kg} \mathrm{ha}^{-1}$ phosphorus, replicated three times. Data collected included weight, quantity and quality of tubers. The data was analysed using analysis of variance (ANOVA) at $5 \%$ confidence levels with General Statistics (GENSTAT) and excel soft wares. Results indicated that phosphorus fertilizer influenced "ware" potato yield. At Saboti application of 120 and $90 \mathrm{~kg}$ phosphorus ha ${ }^{-1}$ for Shangi and Unica resulted in highest "ware" yield of 19.6 and $40.2 \mathrm{t} \mathrm{ha}^{-1}$, respectively. At Ainabkoi application of $120 \mathrm{~kg}$ $\mathrm{ha}^{-1}$ phosphorus produced highest "ware" potato yields of $10.7 \mathrm{t} \mathrm{ha}^{-1}$ and $26.8 \mathrm{t} \mathrm{ha}^{-1}$ of Shangi and Unica, respectively. At Lari, application of 90 and $120 \mathrm{~kg} \mathrm{ha}^{-1}$ phosphorus produced highest "ware" potato yield of $7.0 \mathrm{t}$ $\mathrm{ha}^{-1}$ and $17.5 \mathrm{t} \mathrm{ha}^{-1}$ for Shangi and Unica, respectively. During the season, there was a build-up of soil available phosphorus. Thus, there is need for farmers to test their soil at the beginning of every potato growing season.
\end{abstract}

Keywords: phosphorus rate, highest yield, "ware" potato, available soil phosphorus, tuber phosphorus, physical quality

\section{Introduction}

Potato (Solanum tuberosum $L$ ) is the second most important food crop after maize in Kenya and also the world's most important tuber crop grown in more than 150 countries (FAO, 2019; Wang, 2008). Currently one out of eight billion people in the world eats potato (CIP, 2020). It originated from Andes, in South America (FAO, 2008), was taken to Ireland and later introduced into Kenya by the white settlers in 1880s (Spooner et al., 2005). In Kenya, it is commonly called "Irish potato" because it came from Ireland in 1800 s when the country was hard hit by the great Irish famine that was the worst agricultural, social and cultural disasters of the time that claimed one out of eight million people (FAO, 2008). In 1880s, it was grown for the first time in Kiambu, Nyeri and Muranga counties (NPCK, 2016). About 800,000 farmers (Out of which 500, 000 are small scale) grow potato mainly in five counties (Nyandarua, Uasin-Gishu, Meru, Nakuru and Nandi) on about 192,341 ha (FAO, 2019; Shawiza, 2017).

Potato is a food and cash crop with multipurpose domestic and industrial uses. Domestic uses include consumption as French fries, "bhajia", crisp and mashed potato, etc as well as livestock feed while industrial uses include production of starch, soap and ethanol (KEPHIS, 2016). It is a good source of carbohydrate; protein; 
vitamin B1, B3, B6 and C; fibre; Iron; Zinc and Potassium (Carl et al., 2014). It is also naturally low in fat, cholesterol and sodium with antioxidants properties, making it healthy for human consumption (Duroy et al., 2009). Thus it greatly contributes to alleviating poverty and food insecurity (Abongo \& Kabira, 2013).

Potato grows best in altitudes of 1500 to $3000 \mathrm{~m}$ above sea level (KEPHIS, 2016). However, with proper management and proper use of technology, the crop can grow well in lower altitude areas (Lutaladio et al., 2009). Rainfall of about $750 \mathrm{~mm}$ and optimal temperatures of between $15{ }^{\circ} \mathrm{C}$ and $20{ }^{\circ} \mathrm{C}$ are required during the growing period (KEPHIS, 2016 and MOA, 2011).

The crop requires well drained, high organic matter, fertile and loam textured soils with $\mathrm{pH}$ ranging 4.5 to 8.5 (MOA, 2011 and KEPHIS, 2016). The major nutritional requirements of the crop are potassium (K), nitrogen (N) and phosphorus $(\mathrm{P})$. It is suggested to have the three nutrients in the ratio of 1:1:1 to avoid spoiling tuber quality (Lutaladio et al., 2009). In 2017, Kenya with a production of about 1.5 million tones was the $6^{\text {th }}$ best African country in potato production after Algeria, Egypt, South Africa, Morocco and Tanzania. Between 2007 and 2017, on average, Kenya's area under production, yield and total annual production were 135,677 ha, $16.6 \mathrm{t} \mathrm{ha}^{-1}$ and 2.3 million tones, respectively. In the same period, area under potato production increased by about 56,664 ha. However, potato yield declined by about $8.7 \mathrm{t} \mathrm{ha}^{-1}$ in the same period (FAO, 2019). This could be caused by the many challenges facing potato production which include high incidences of pests and diseases; weak research-extension linkage; poor market infrastructure; declining soil fertility; use of low quality and/or low supply of clean and certified seed (Muthoni, 2016; Karanja et al., 2014).

There is great need for rapid interventions to improve yield of potato production in Kenya. Unfortunately, this is hindered by inadequate extension services, erratic rainfall, pests, diseases and most importantly low and declining soil fertility (Karanja et al., 2014).

Deficiency of phosphorus has been reported in major potato producing areas in Kenya (Muthoni, 2016; NAAIAP, 2014). This could impact negatively on the "ware" potato yields. The nutrient affect tuber skin setting; dry matter accumulation; time to maturity; storage quality of tubers; tuber size and tuber protein, nitrate and reducing sugar content (Tuhin et al., 2007; Lutaladio et al., 2009; Muthoni, 2016;). The current "ware" potato fertilizer recommendations are "blanket" and outdated. Updated and more specific phosphorus fertilizer rate recommendations are expected to contribute to improving "ware" potato yields and production in Kenya. Therefore, this research focused on influence of application of phosphorus fertilizer on "ware" potato yields in Lari, Ainabkoi and Saboti Sub Counties. The broad objective of the study was to increase "ware" potato production in Kenya through enhanced soil fertility particularly phosphorus in the main potato producing sub counties of Kenya while the specific objective of the same study was to determine influence of phosphorus fertilizer on "ware" potato yield and quality.

\section{Materials and Methods}

\subsection{Description of the Study Sites}

This study was carried out in three locations: Saboti, Ainabkoi and Lari (Figure 1). Saboti $\left(0.94{ }^{\circ} \mathrm{N}, 34.84{ }^{\circ} \mathrm{E}\right)$ is in Trans Nzoia County at an elevation of $1923 \mathrm{~m}$ above sea level. Its soils are humic nitosols while its agro ecological zone is Upper midland (Maize and coffee zone). It receives 1000 to $1200 \mathrm{~mm}$ of rainfall annually and has temperature range of 10 to $27^{\circ} \mathrm{C}$. Ainabkoi $\left(0.18^{\circ} \mathrm{N}, 35.53^{\circ} \mathrm{E}\right)$ is in Uasin Gishu County at an altitude of $2300 \mathrm{~m}$ above sea level. Its agro ecological zone is Upper Highland Zone 2 (UH2) which is a pyrethrum and wheat zone. The area receives annual rainfall of about 1200 to $1400 \mathrm{~mm}$. Its annual temperature ranges between 13.3 to $15.7{ }^{\circ} \mathrm{C}$. Its soil type is humic Nitisols. Lari $\left(1.11^{\circ} \mathrm{S}, 36.64{ }^{\circ} \mathrm{E}\right)$ is in Kiambu County. It has an elevation of $2550 \mathrm{~m}$ above sea level, annual rainfall of $1400 \mathrm{~mm}$, temperature of 12 to $21^{\circ} \mathrm{C}$ and an agro ecological zone of Upper highland 1 (Pyrethrum and Dairy zone). Its soils are planosols (NAIAAP, 2014; Jaetzold and Schmidt, 2009; Jaetzold et al., 2011). 


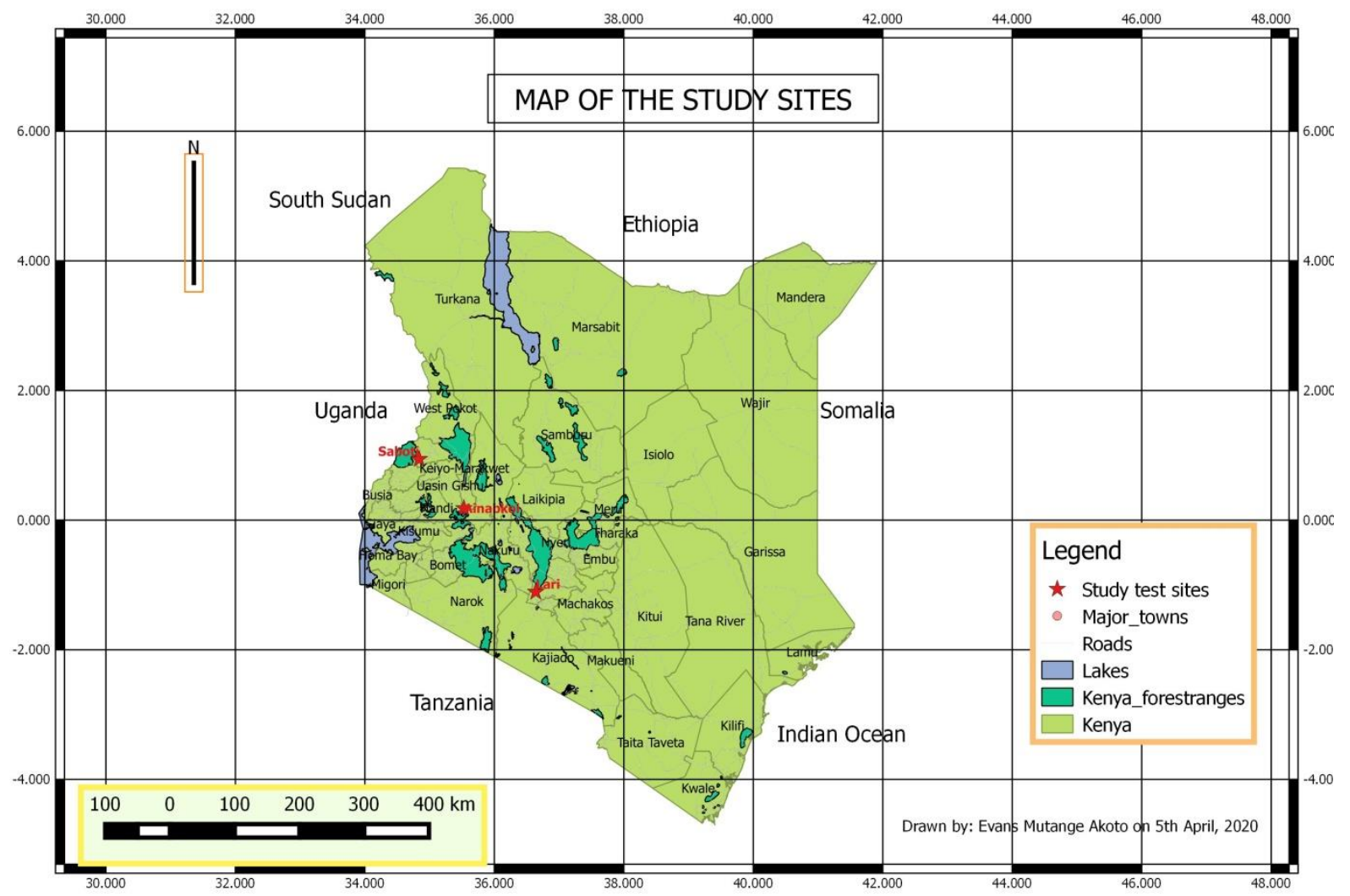

Figure 1. Location of the study sites (Source: First hand data by GPS machine; ILRI (2015) and Open Africa (2020)

\subsection{Test Potato Varieties}

The test varieties were Unica and Shangi. Unica was selected based on its high yielding potential (> $45 \mathrm{t}$ ha-1) and suitability for chips, crisps and domestic uses. It is rich in vitamin C, iron and zinc. Shangi was selected based on its popularity with farmers and its local availability. Unica is an alternative to Shangi which has low storage time (NPCK, 2019).

\subsection{Experimental Treatments and Coding}

Table 1 below gives experimental treatments, staring with $(0 \mathrm{~N} \& 0 \mathrm{P})$ where both nitrogen and phosphorus fertilizers were not applied. In the remaining treatments, nitrogen was applied as a basal fertilizer at the rate of $90 \mathrm{~kg}$ nitrogen $\mathrm{ha}^{-1}$ as urea. Phosphorus was also applied at the same time at the rate of $0,30,60,90,120 \mathrm{~kg}$ phosphorus ha ${ }^{-1}$ as Triple Supper Phosphate. The Nitrogen rate of $90 \mathrm{~kg} \mathrm{ha}^{-1}$ and phosphorus rate of $90 \mathrm{~kg} \mathrm{ha}^{-1}$ were based on (Kaguongo et al., 2008; MOA, 2011, KARI, 2008 and NPCK, 2013). These recommendations are backed by Lutaladio, 2009 who recommends nitrogen: phosphorus ratio of 1:1 for potato production. They are recommended rates for "ware" potato production. Potassium was not tested as it was found to be high or adequate in the test sites. 
Table 1. Phosphorus fertilizer treatments and coding

\begin{tabular}{|c|c|c|c|}
\hline \multirow{2}{*}{$\begin{array}{l}\text { Treatment } \\
\text { Number }\end{array}$} & \multicolumn{2}{|r|}{ Description } & \multirow[t]{2}{*}{ Code } \\
\hline & Rates of $P$ per ha & $\begin{array}{l}\text { Rates plant }{ }^{-1}: \boldsymbol{T S P}=0.093 \times \text { Pgrams per plant }(\mathrm{P} \text { in } \mathrm{kg} / \mathrm{ha}) \\
\text { Urea }=0.041 \mathrm{~N} \text { grams perplant }(N \text { in } \mathrm{kg} / \mathrm{ha})\end{array}$ & \\
\hline 1 & 0N, OP (Ideal Control) & 0 g Urea, 0 g TSP plant ${ }^{-1}$ & $\mathrm{IC}$ \\
\hline 2 & $0 \mathrm{~kg} \mathrm{Pha}^{-1}$ & 0 g TSP plant ${ }^{-1}$ & P0 \\
\hline 3 & $30 \mathrm{~kg} \mathrm{P} \mathrm{ha}^{-1}$ & $2.8 \mathrm{~g}_{\text {TSP plant }}{ }^{-1}$ & P1 \\
\hline 4 & $60 \mathrm{~kg} \mathrm{P} \mathrm{ha}^{-1}$ & $5.6 \mathrm{~g}$ TSP plant ${ }^{-1}$ & $\mathrm{P} 2$ \\
\hline 5 & $90 \mathrm{~kg} \mathrm{Pha}^{-1}$ & 8.4. $\mathrm{g} \mathrm{TSP}_{\text {plant }}{ }^{-1}$ & P3 \\
\hline 6 & $120 \mathrm{~kg} \mathrm{Pha}^{-1}$ & $11.2 \mathrm{~g} \mathrm{TSP}$ plant ${ }^{-1}$ & P4 \\
\hline
\end{tabular}

Basal application of nitrogen at $90 \mathrm{~kg} \mathrm{ha}^{-1}\left(3.6 \mathrm{~g} \mathrm{Urea} \mathrm{plant}^{-1}\right)$ was applied to all plants except in ideal control plots.

\subsection{Experimental Layout}

As indicated in Table 2, the experimental lay out had 36 experimental units in three blocks, two treatments of variety and six treatments of phosphorus rate. The main (whole) plot treatments are varieties while the sub plot treatments are phosphorus rates which included ideal controls $(0 \mathrm{~N}, 0 \mathrm{P})$.

Table 2. Experimental layout

\begin{tabular}{llllll}
\hline \multicolumn{2}{ll}{ Block 1 } & \multicolumn{2}{l}{ Block 2 } & \multicolumn{2}{l}{ Block 3 } \\
\hline \multicolumn{2}{l}{ Main plots: Varieties } & \multicolumn{2}{l}{ Main plots: Varieties } & \multicolumn{2}{l}{ Main plots: Varieties } \\
\hline Unica & Shangi & Shangi & Unica & Unica & Shangi \\
\hline P0 & P2 & IC & P3 & P4 & P1 \\
P4 & IC & P0 & P2 & P3 & P4 \\
P1 & P3 & P4 & IC & P2 & P0 \\
P3 & P4 & P2 & P1 & P0 & IC \\
IC & P0 & P1 & P4 & P1 & P2 \\
P2 & P1 & P3 & P0 & IC & P3 \\
\hline
\end{tabular}

\subsection{Soil Sampling and Seed Bed Preparation.}

Land was ploughed before the onset of rains and sub divided into 36 experimental units. The size of each unit was $4 \mathrm{~m}$ by $3 \mathrm{~m}$ surrounded by $1 \mathrm{~m}$ wide path. In each site, the total area needed for the study was therefore 0.23 ha. Two composite soil samples $(0-15 \mathrm{~cm}$ and $15-30 \mathrm{~cm})$ were taken in grid style before planting. Further, soil samples $(0-15 \mathrm{~cm})$ were taken at harvesting in grid style in each experimental unit.

\subsection{Planting, Ridging, Weeding, Diseases and Pests Management}

The seed used for planting was of good quality (KEPHIS, 2016). The seed was large grade (45 mm to $60 \mathrm{~mm}$ diameter). The seed was planted at a spacing of $75 \mathrm{~cm}$ between rows and $25 \mathrm{~cm}$ within rows. Planting was done at the onset of long rains where fertilizers were well worked in the soil to avoid scorching the seed. Well sprouted seed tubers were then placed in the furrow and covered with soil immediately. Fertilizers were applied according to the treatment plan (Table $1 \& 2$ ).Ridging or earthing up was done concurrently with weeding at 30 to 45 days after planting. Pesticides and fungicides were applied according to need to control pests and diseases.

\subsection{Dehaulming, Harvesting and Post-harvest Handling}

When the tops of the potatoes started to turn yellow (physiological maturity), their above ground biomass was cut ("dehaulmed") and tubers left for two weeks for their skin to harden before harvesting. Harvesting was done in the morning and late in the afternoon when temperatures were warm and soils were moist but not wet to minimize scorching of tubers caused by the bright sunlight. The harvest of the two end rows and the last two plants per raw were separated from the rest of the plants before storage since they were not used in data analysis.

\subsection{Potato Yield Data}

Potato yields whose diameter was greater than $60 \mathrm{~mm}$ ("ware" potatoes according to KEPHIS, 2016) were determined using equation 1.

$$
\mathrm{G}_{1}=\frac{10000}{0.25 \times 0.75 \times 1000} \times \mathrm{Y}
$$


Where: $\mathrm{G}_{1}=$ Yield in $\mathrm{t} \mathrm{ha}^{-1} ; \mathrm{Y}=$ Average yield $(\mathrm{kg})$ of sampled plants $=$ Weight $(\mathrm{kg})$ of sampled plants/Number of plants sampled (18 plants).

\subsection{Determination of "Ware" Potato Quality}

The quality tested was physical. It was determined by the farmer and the trader. Some of the parameters investigated were subjective and dynamic. The parameters tested included demand, taste (palatability), pealing and cooking. They were tested through physical observations at harvest.

\subsection{Laboratory Analysis}

Soil samples at planting were analyzed at the National Agricultural Research Laboratories (NARL) using Mehlich 3 protocol which extracts soil nutrients using double acid decomposition. They were analyzed for $\mathrm{pH}$, available phosphorus, total nitrogen, soil total organic carbon, exchangeable acidity (Lari only), potassium (K), calcium $(\mathrm{Ca})$, magnesium $(\mathrm{Mg})$, copper $(\mathrm{Cu})$, iron $(\mathrm{Fe})$, zinc $(\mathrm{Zn})$ and sodium $(\mathrm{Na})$ (Harova and Spejra, 2014 ; Agro Eco Lab, 2016). Further, samples taken at planting and harvesting were also analyzed for available phosphorus using Bray 2 procedures as outlined by Okalebo et al., 2002. The Bray 2 extracting solution was a solution of $0.03 \mathrm{M}$ ammonium fluoride and $0.1 \mathrm{M}$ hydrochloric acid. Total phosphorus in potato tubers was extracted using a digestion mixture of hydrogen peroxide + concentrated sulphuric acid + selenium powder + salicylic acid) at elevated temperatures of 110 to $330^{\circ} \mathrm{C}$. After extraction of available phosphorus, the concentration of phosphorous in sample solutions was determined calorimetrically.

\subsection{Statistical Analysis}

All data was subjected to analysis of variance (ANOVA) using General Statistics (GENSTAT) soft"ware" at 5\% confidence level. Also, the same software and excel software were used in determining Pearson correlation coefficiencies particularly between the overall "ware" potato yield and phosphorous rates, soil available phosphorus and plant (tuber) phosphorus.

The linear statistical model for the split-plot design is:

$\mathrm{Y}_{\mathrm{ijk}}=\mu+\mathrm{V}_{\mathrm{i}}+\mathrm{B}_{\mathrm{j}}+\varepsilon_{1(\mathrm{ij})}+\mathrm{P}_{(\mathrm{k})}+\mathrm{VP}_{(\mathrm{ik})}+\varepsilon_{2(\mathrm{ijk})}$; Where $\mathrm{Y}_{\mathrm{ijk}}=$ Total effect of the treatments; $\mu=$ Mean effect; $\mathrm{V}_{\mathrm{i}}=$ The $\mathrm{i}^{\text {th }}$ effect of variety $(\mathrm{V}) ; \mathrm{B}_{\mathrm{j}}=$ The $\mathrm{j}^{\text {th }}$ effect of blocks; $\varepsilon_{1(i \mathrm{j})}=$ Main plot error; $\mathrm{P}_{(\mathrm{k})}=$ The $\mathrm{k}^{\text {th }}$ effect of phosphorus $(\mathrm{P}) ; \mathrm{VP}_{(\mathrm{ik})}=$ Effect due to interaction between variety $(\mathrm{V})$ and phosphorus $(\mathrm{P})$ and $\varepsilon_{2(i \mathrm{jk})}=$ Split plot Error.

The Skeletal Analysis of Variance table: Each of the three sites was divided into three blocks (replicates), each block was divided into two main (whole) plots and each whole plots was divided into six (6) sub plots. Each whole plot was planted with two seed potato test varieties (Shangi and Unica) at random. Each variety was planted in six sub plots. Each sub plot was treated with its own phosphorus rate at random. Nitrogen was applied as a basal nutrient at the rate of $90 \mathrm{~kg} \mathrm{ha}^{-1}$ while the plot with $0 \mathrm{~kg} \mathrm{ha}^{-1}$ phosphorus was the normal control plot. There was provision for ideal control (IC) plots without phosphorus and nitrogen (Table 3).

Table 3. Skeletal Analysis of variance (ANOVA)

\begin{tabular}{|c|c|c|c|c|c|}
\hline SOV & df & SS & MS & Fcal & P-value \\
\hline Blocks or replications (B) & $\mathrm{b}-1=2$ & $\mathrm{~B}_{\mathrm{cc}}$ & $\mathrm{B}_{\mathrm{MC}}$ & $\mathrm{B}_{\mathrm{cc}} / \mathrm{E}_{\mathrm{M}}$ & By GENSTAT \\
\hline Main plots : Varieties (V) & $\mathrm{v}-1=1$ & $\mathrm{~V}_{\mathrm{cs}}$ & $\mathrm{V}_{\mathrm{ug}}$ & $\mathrm{V}_{\mathrm{cc}} / \mathrm{E}_{\mathrm{Mc}}$ & By GENSTAT \\
\hline Main plot Error ( $\mathrm{V} x \mathrm{~B})$ or Error (a) & $(\mathrm{b}-1)(\mathrm{v}-1)=2$ & $\mathrm{E}_{\mathrm{cc}(\mathrm{n})}^{\mathrm{cc}}$ & 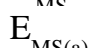 & & \\
\hline Sub-plots: $\mathrm{P}$ rates & $\mathrm{p}-1=5$ & $\mathrm{P}_{\mathrm{cc}}^{\mathrm{cc}}$ & $\mathrm{P}_{\mathrm{Mc}}^{\mathrm{xam}}$ & $\mathrm{P}_{\mathrm{cs}} / \mathrm{E}_{\mathrm{asc}}$ & By GENSTAT \\
\hline V x P-rates & $(\mathrm{v}-1)(\mathrm{p}-1)=5$ & $\mathrm{VP}_{\mathrm{cc}}$ & $\mathrm{VP}_{\mathrm{Mc}}$ & $\mathrm{VP}_{\mathrm{cc}} / \mathrm{E}_{\mathrm{a} \alpha \mathrm{c} / \mathrm{h}}$ & By GENSTAT \\
\hline Sub plot error $\mathrm{V}(\mathrm{P} \times \mathrm{B})$ or Error $(\mathrm{b})$ & $\mathrm{v}(\mathrm{p}-1)(\mathrm{b}-1)=20$ & $\mathrm{E}_{\mathrm{cc}(\mathrm{s}}$ & $\mathrm{E}_{\mathrm{ancm}}$ & & \\
\hline Total & bvp- $1=35$ & $\mathrm{~T}_{\mathrm{cs}}$ & $\mathrm{T}_{M \mathrm{~S}}$ & & \\
\hline
\end{tabular}

\section{Results and Discussion}

\subsection{Soil Characteristics of Test Sites Prior to Treatment Applications and at Harvesting}

The chemical characterization of the top $0-15 \mathrm{~cm}$ soils from the three test sites at planting showed that they were acidic. Lari with a pH of 4.6 was strongly acidic while Ainabkoi and Saboti with $\mathrm{pH}$ of 5.6 and 5.8, respectively were moderately acidic. The available soil phosphorus levels were low at Lari, adequate at Ainabkoi and high at Saboti. In all the three test sites, potassium was adequate. Saboti and Ainabkoi had adequate soil zinc while Lari had low soil zinc levels. In all the test sites, total nitrogen was adequate except in the $15-30 \mathrm{~cm}$ depth in Ainabkoi where it was low. Total organic carbon was adequate in Saboti and Lari but moderate in Ainabkoi. 
Exchangeable acidity in Lari was adequate (Table 4).

Table 4. Chemical properties of the surface soils $(0-15 \mathrm{~cm}$ and $15-30 \mathrm{~cm})$ taken before planting (2019 long rains) at three experimental sites in Kenya. Bolded figures indicate low quantities

\begin{tabular}{|c|c|c|c|c|c|c|c|}
\hline \multirow{2}{*}{$\begin{array}{l}\text { Soil property } \\
\text { Depth of soil sample }(\mathrm{cm})\end{array}$} & \multirow{2}{*}{$\begin{array}{l}\text { Critical value } \\
\text { N/A }\end{array}$} & \multicolumn{2}{|l|}{ Saboti } & \multicolumn{2}{|c|}{ Ainabkoi } & \multicolumn{2}{|l|}{ Lari } \\
\hline & & $0-15$ & $15-30$ & $0-15$ & $15-30$ & $0-15$ & $15-30$ \\
\hline Soil pH (1: 2.5 Soil: Water) & $\geq 5.5$ & 5.83 & 5.67 & 5.62 & 5.59 & 4.6 & 4.83 \\
\hline Exchangeable acidity (me \%) & & & & & & 0.4 & 0.4 \\
\hline Total nitrogen $(\%)$ & $\geq 0.2$ & 0.34 & 0.30 & 0.24 & 0.18 & 0.25 & 0.24 \\
\hline Total Organic carbon $(\%)$ & $\geq 2.7$ & 3.55 & 3.13 & 2.54 & 2.01 & 2.7 & 2.51 \\
\hline Phosphorus (ppm) & $\geq 30$ & 45 & 45 & 40 & 35 & 25 & 30 \\
\hline Potassium (me \%) & $\geq 0.24$ & 1.00 & 0.41 & 2.03 & 2.03 & 0.71 & 0.69 \\
\hline Calcium (me \%) & $\geq 2.0$ & 26.0 & 26.8 & 14.2 & 10.2 & 1.4 & 1.2 \\
\hline Magnesium (me \%) & $\geq 1.0$ & 4.06 & 5.10 & 4.04 & 3.56 & 0.79 & 0.82 \\
\hline Manganese (me \%) & $\geq 1.0$ & 0.96 & 0.62 & 0.64 & 0.67 & 0.48 & 0.36 \\
\hline Copper (ppm) & $\geq 1.0$ & 9.83 & 9.71 & 2.50 & 2.15 & 2.4 & 2.1 \\
\hline Iron (ppm) & $\geq 10$ & 16.1 & 17.2 & 16.2 & 17.8 & 220 & 224 \\
\hline Zinc (ppm) & $\geq 5$ & 2.46 & 1.40 & 4.31 & 3.84 & 8.58 & 5.29 \\
\hline Sodium (me \%) & N/A & 0.50 & 0.54 & 0.50 & 0.48 & 0.62 & 0.86 \\
\hline Soil colour & N/A & $\begin{array}{l}\text { Dark } \\
\text { brown }\end{array}$ & $\begin{array}{l}\text { Dark } \\
\text { reddish brown }\end{array}$ & $\begin{array}{l}\text { Dark } \\
\text { brown }\end{array}$ & $\begin{array}{l}\text { Reddish } \\
\text { brown }\end{array}$ & Grey & $\begin{array}{l}\text { Greyish } \\
\text { Red }\end{array}$ \\
\hline Stickness & N/A & Less st & & More S & icker & Less $\mathrm{s}$ & \\
\hline Soil type & N/A & Nitisol & & Nitisol & & Plano & \\
\hline Vegetation & & $\begin{array}{l}\text { Maize, } \\
\text { beans, }\end{array}$ & $\begin{array}{l}\text { otatoes, } \\
\text { ees }\end{array}$ & $\begin{array}{l}\text { Maize, } \\
\text { beans, }\end{array}$ & $\begin{array}{l}\text { otatoes, } \\
\text { ees }\end{array}$ & $\begin{array}{l}\text { Scattr } \\
\text { trees, }\end{array}$ & $\begin{array}{l}\text { hrubs and } \\
\text { ze, potatoes }\end{array}$ \\
\hline Water Table & & $\operatorname{Deep}(>$ & & Deep ( & $3 \mathrm{~m})$ & Shallo & $<3 m)$ \\
\hline
\end{tabular}

Source of critical values: NAAAIAP (2014)

\section{Soil available and plant (tuber) phosphorus in the test sites}

Soil available phosphorus at planting and harvesting were highest at Saboti, average at Ainabkoi and lowest at Lari. Plant (tuber) phosphorus was highest at Saboti. The plant tuber phosphorus at Ainabkoi and Lari were not significantly different. There was a strong positive correlation $(r=+0.7)$ between mean available soil available phosphorus and mean plant (tuber) phosphorus. Correlation between mean soil available phosphorus at planting and mean soil available phosphorus at harvesting was perfect $(\mathrm{r}=+1.0)$ (Figure 2 and 3).

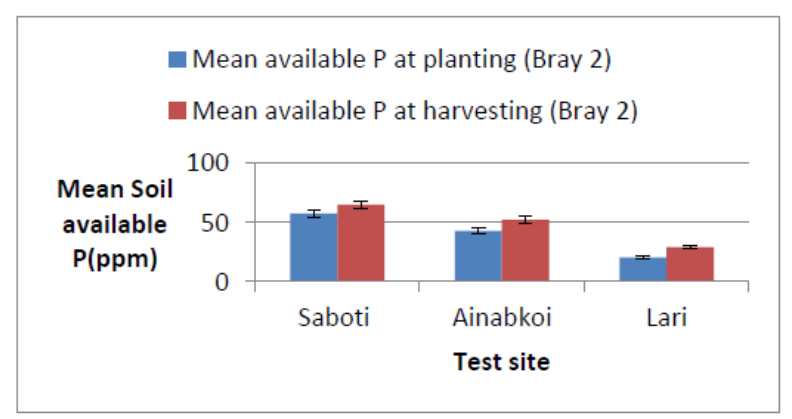

Figure 2. Soil available Phosphorus in the test sites (The error bars are percentage type (5\%) 


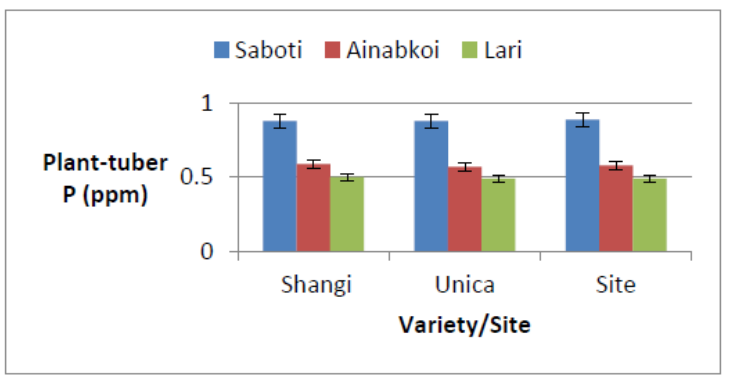

Figure 3. Plant (Tuber) phosphorus at harvesting (The error bars are percentage type (5\%)

\subsection{Influence of Phosphorus Fertilizer Rates on "Ware" Potato Yield}

\section{Influence of Phosphorus on "ware" potato yield at Saboti.}

The results indicate that variety $(\mathrm{p}=0.036)$, phosphorus $(\mathrm{p}=0.002)$ and interaction between phosphorus and variety significantly $(p=0.005)$ influenced yield of "ware" potatoes. The mean yield of Shangi was $13.9 \mathrm{t} \mathrm{ha}^{-1}$ while that of Unica was $24.6 \mathrm{t} \mathrm{ha}^{-1}$. Highest yield of Shangi $\left(19.6 \mathrm{t} \mathrm{ha}^{-1}\right)$ was realized with $120 \mathrm{~kg} \mathrm{ha}^{-1}$ phosphorous while Unica's highest yield $\left(40.2 \mathrm{t} \mathrm{ha}^{-1}\right)$ was achieved with phosphorus rate of $90 \mathrm{~kg} \mathrm{ha}{ }^{-1}$. Correlation between phosphorus rate and mean tuber yield was strongly positive $(\mathrm{r}=+0.7)$. Also, correlation between phosphorus rate and tuber yield of Shangi $(r=+0.5)$ and Unica $(r=+0.6)$ was positive (Table 5). As much as the available soil phosphorus was high in Saboti (40 ppm Mehlich 3 phosphorus), it was necessary to add more phosphorus to maximize yield. Farmers in the area apply phosphorus fertilizers to their soils when planting potatoes. However, they need more information on the appropriate rate of fertilizers to apply. This can only happen when recommendations on fertilizer rates for potatoes are revised, updated and made area specific. The above findings compares well with those of MOA (2011), Kaguongo (2008), NPCK (2013) and KARI (2008) which notes a "blanket" recommendation of $90 \mathrm{~kg} \mathrm{ha}^{-1}$ phosphorus for "ware" potato production in Kenya. Khalid et al., 2003 noted that different varieties of potatoes yielded differently in response to phosphorus application. From studies done in Ethiopia by Israel et al., 2012 on the influence of nitrogen and phosphorus on potato production, it was found that phosphorus rate of $60 \mathrm{~kg} \mathrm{ha}^{-1}$ and nitrogen rate of $165 \mathrm{~kg} \mathrm{ha}^{-1}$ gave optimum yields. The yields of Shangi $\left(13.9 \mathrm{t} \mathrm{ha}^{-1}\right)$ and Unica $\left(24.6 \mathrm{t} \mathrm{ha}^{-1}\right)$ varieties differed significantly. This is confirmed by NPCK (2019) which has noted that Unica $\left(>45 \mathrm{t} \mathrm{ha}^{-1}\right.$ ) has more yield potential than Shangi (35 to $40 \mathrm{t} \mathrm{ha}^{-1}$ )

\section{Influence of phosphorus on "ware" potato yield of potato at Ainabkoi.}

The results indicate that yields of varieties had marginal significant $(p=0.06)$ difference. Phosphorus $(p<0.001)$ and interaction between phosphorus and variety significantly $(p=0.002)$ influenced tuber yield of "ware" potatoes. The mean yield of Shangi was $7.2 \mathrm{t} \mathrm{ha}^{-1}$ while that of Unica was $12.1 \mathrm{t} \mathrm{ha}^{-1}$. The highest yield of Shangi $\left(10.7 \mathrm{t} \mathrm{ha}^{-1}\right)$ and Unica $\left(26.8 \mathrm{t} \mathrm{ha}^{-1}\right)$ were both realized with $120 \mathrm{~kg} \mathrm{ha}^{-1}$ phosphorous. Correlation between phosphorus rate and mean "ware" tuber yield was strongly positive $(\mathrm{r}=+0.9)$. Also, Correlation between phosphorus rate and "ware" tuber yield of Shangi $(\mathrm{r}=+0.6)$ and Unica $(\mathrm{r}=+0.9)$ was strong (Table 5). The difference in the yields of varieties has also been noted by NPCK (2017) that has documented the potential yield of Unica to be greater than that of Shangi. These results are within the blanket recommendations of $90 \mathrm{~kg} \mathrm{ha}^{-1}$ phosphorus for "ware" potato by MOA (2010), Kaguongo (2008), KARI (2008) and NPCK (2013). In a similar study on potatoes, Birtukan (2016) recommended phosphorous rate of $135 \mathrm{~kg} \mathrm{ha}^{-1}$.

\section{Influence of phosphorus on "ware" potato yield of potato at Lari.}

The results show that there was significant difference $(p=0.024)$ between the mean potato "ware" yields of Shangi $\left(5.1 \mathrm{t} \mathrm{ha}^{-1}\right)$ and Unica $\left(12.6 \mathrm{t} \mathrm{ha}^{-1}\right)$. Phosphorus rate significantly $(\mathrm{p}<0.001)$ influenced potato "ware" yield. Correlation between phosphorus rate and mean potato yield was strongly positive $(\mathrm{r}=+0.8)$. Interaction between phosphorus rate and variety significantly $(\mathrm{p}=0.004)$ influenced "ware" potato yield. The highest yield of Shangi $\left(7.0 \mathrm{t} \mathrm{ha}^{-1}\right)$ was realized at phosphorus rate of $90 \mathrm{~kg} \mathrm{ha}^{-1}$ while the highest "ware" yield of Unica (17.5 $\mathrm{t} \mathrm{ha}^{-1}$ ) was realized at phosphorus rate of $120 \mathrm{~kg} \mathrm{ha}^{-1}$. The correlation between phosphorus rate and mean "ware" yield of Shangi $(r=+0.9)$ and Unica $(r=+0.4)$ was positive (Table 5). In this site, initial soil available phosphorus status (25 ppm Mehlich 3 Phosphorus) was below the critical level of (30 ppm Mehlich 3 phosphorus). At planting, the area was surrounded with maize that was purplish in colour confirming low soil available phosphorus. The water table of the area was high $(1-3 \mathrm{~m})$ necessitating construction and maintenance of drainage channels. There were indications of illuviation as the colour of the top soil was greyish brown. In this 
site, additional phosphorus is justified by the above mentioned low available soil phosphorus at planting. The above findings compares well with those of MOA (2011), Kaguongo (2008), NPCK (2013) and KARI (2008) which notes a blanket recommendation of $90 \mathrm{~kg} \mathrm{ha}^{-1}$ phosphorus for "ware" potato production in Kenya. In a similar study conducted by Zelalem et al., 2009 in Central highlands of Ethiopia, phosphorus application of 120 $\mathrm{kg} \mathrm{ha}^{-1}$ was optimum for potato production. Correlation between yields and tuber numbers was positive. The correlation between Shangi "ware" yield and numbers was +0.4 while the correlation between Unica's "ware" yield and tuber numbers was +0.8 . Israel et al., 2012 found that phosphorus application of $60 \mathrm{~kg} \mathrm{ha}^{-1}$ was optimum for potato production. From Birturkan (2016), phosphorus needed for optimum potato production was $135 \mathrm{~kg} \mathrm{ha}^{-1}$ phosphorus. This is confirmed by Ekelorf (2007) who has said that there are several factors that contribute to fertilizer recommendations on potatoes which include soil type, nutrient availability, and economic factors of an area, moisture supply and variety. It is therefore important to base crop fertilizer requirements on soil test results (Yara International, 2019).

Table 5. Influence of phosphorus on "ware" potato yield

\begin{tabular}{|c|c|c|c|c|c|c|c|c|c|}
\hline \multirow[t]{3}{*}{ Phosphorus (kg ha ${ }^{-1}$ ) } & \multicolumn{9}{|c|}{ Mean Variety yield $\left(\mathrm{t} \mathrm{ha}^{-1}\right)$} \\
\hline & \multicolumn{3}{|l|}{ Saboti } & \multicolumn{3}{|c|}{ Ainabkoi } & \multicolumn{3}{|l|}{ Lari } \\
\hline & Shangi & Unic: & Mean & Shangi & Unica & Mean & Shangi & Unica & Mean \\
\hline IC & 8.2 & 17.3 & 12.8 & 1.3 & 6.7 & 4.0 & 2.1 & 8.6 & 5.3 \\
\hline 0 & 17.2 & 19.2 & 18.2 & 7.3 & 4.9 & 6.1 & 2.6 & 4.5 & 3.6 \\
\hline 30 & 11.8 & 15.1 & 13.4 & 9.5 & 8.6 & 9.1 & 7.0 & 15.7 & 11.4 \\
\hline 60 & 13.7 & 31.9 & 22.8 & 8.2 & 8.9 & 8.5 & 5.0 & 13.2 & 9.1 \\
\hline 90 & 13.0 & 40.2 & 26.6 & 6.2 & 16.5 & 11.4 & 7.0 & 16.2 & 11.6 \\
\hline 120 & 19.6 & 23.9 & 21.7 & 10.7 & 26.8 & 18.7 & 6.6 & 17.5 & 12.0 \\
\hline \multirow[t]{6}{*}{ Mean } & 13.9 & 24.6 & 19.2 & 7.2 & 12.1 & 9.6 & 5.1 & 12.6 & 8.8 \\
\hline & \multirow{2}{*}{\multicolumn{3}{|c|}{$\mathbf{L S D}_{\mathbf{p}=\mathbf{0 . 0 5}}$}} & & \multicolumn{2}{|c|}{$\operatorname{LSD}_{p=0.05}$} & & \multicolumn{2}{|r|}{$\operatorname{LSD}_{\mathrm{p}=0.05}$} \\
\hline & & & & \multirow{2}{*}{\multicolumn{2}{|c|}{$\begin{array}{l}\text { Variety } \\
\text { Phosphorus }\end{array}$}} & \multirow{2}{*}{$\begin{array}{l}=5.3 \\
=4.3\end{array}$} & \multirow{2}{*}{\multicolumn{2}{|c|}{$\begin{array}{l}\text { Variety } \\
\text { Phosnhorus }\end{array}$}} & $=5.1$ \\
\hline & \multicolumn{2}{|c|}{ Phosphorus } & & & & & & & $=2.7$ \\
\hline & \multicolumn{2}{|c|}{ Phosphorus* } & & \multicolumn{2}{|c|}{$\begin{array}{l}\text { Phosphorus* } \\
\text { Variety }\end{array}$} & & \multicolumn{2}{|c|}{$\begin{array}{l}\text { Phosphorus* } \\
\text { Variety }\end{array}$} & $=4.4$ \\
\hline & \multicolumn{3}{|l|}{29.2} & \multicolumn{3}{|l|}{373} & \\
\hline
\end{tabular}

\subsection{Influence of Variety on Quality of "Ware" Potato}

There were similarities and diffrences between the physical qualities of the two potato varieties. Not much information is available on Unica by many consumers and producers since it is among the most recently released varieties in Kenya (NPCK, 2017). Both varieties can be eaten as chips or boiled. They take almost the same duration to cook but Shangi cooks faster and is tastier (Sophie, 2018). Both varieties peel easily but Unica peals more easily than Shangi. Unica is smoother and has fewer eyes than Shangi (NPCK, 2019). Consequently, on average, the time taken to peel a Unica tuber is less than that taken to peel a Shangi tuber. Some consumers prefer Shangi for its white flesh while others prefer Unica for its cream flesh. Unica is noted to be good for crisps, has unique flavour (Sophie, 2018) and its colour blends with "bhajia" type of cooked potato. Some consumers indicated that Shangi is sweeter and cooks faster than Unica. The storage time of Unica (2.5 to 3.5 months) is longer than that of Shangi (Less than 1 month) (NPCK, 2018 \& NPCK, 2019). Thus, Unica is not only good for institutions (like schools, hospitals and prisons) but also for individual households. At such time when the world is faced with the challenge of corona virus (COVID, 19), Unica is preffered as it can remain in good condition for food for longer period than Shangi. Most actors on the potato value chain particularly consumers, traders, intermediaries ("middle men"), seed merchants and producers prefer Shangi. This is because it is more popular; more demanded and has short dormancy than Unica. Sophie (2018) observed that most farmers produced Shangi than other higher yielding varieties like Unica, Tigoni, "Sherehekea", "Desire" and "Asante". This is despite Unica being more resistant to pests and diseases and being more tolerant to other climate change impacts than Shangi (NPCK, 2019; Waikwa, 2018 \& Sophie, 2018).

\section{Comparisons of Key Soil Parameters That Affected Potato Tuber Yield}

There was a strong positive correlation between "ware" potato yield and soil $\mathrm{pH}(\mathrm{r}=+0.7)$; between "ware" potato yield and soil available phosphorus at planting $(\mathrm{r}=+0.7)$; "ware" potato yield and soil available phosphorus at harvesting $(\mathrm{r}=+0.8)$. There was also a positive perfect correlation between "ware" potato yield and plant (tuber) phosphorus at harvesting $(\mathrm{r}=1.0)$. Higher soil $\mathrm{pH}$ in Saboti and Ainabkoi as compared to Lari 
favoured potato tuber yield. According to KEPHIs (2016), potatoes are acid loving but grow optimally in soils with $\mathrm{pH}$ range of 5.5 to 7.0 because most nutrients they require are available in this $\mathrm{pH}$ range. Saboti with $\mathrm{pH}$ of 5.8 produced highest mean potato tuber yield $\left(19.2 \mathrm{t} \mathrm{ha}^{-1}\right)$, Ainabkoi with $\mathrm{pH}$ of 5.6 produced moderate mean potato tuber yield $\left(9.6 \mathrm{tha}^{-1}\right)$ while Lari with $\mathrm{pH}$ of 4.6 produced the lowest mean potato tuber yield $\left(8.8 \mathrm{t} \mathrm{ha}^{-1}\right)$. Low $\mathrm{pH}$ hinders root growth due to toxicicity of micronutrients like Manganese $(\mathrm{CK}, 2020)$ and/or by fixing soil phosphorus (Silvar, 2012) which is essential in root establishment. There was also a perfect correlation $(r=+1.0)$ between soil available phosphorus at planting and soil $\mathrm{pH}$. Studies have shown that phosphorus is fixed in the soil by aluminium or iron ions which are more available in soil solution at low $\mathrm{pH}$ (Silva, 2012). Thus, the availability of phosphorus was lowest in Lari (20.5 ppm Bray 2 phosphorus), average in Ainabkoi (43.0 ppm Bray 2 phosphorus) and highest in Saboti (57.7 ppm Bray 2 phosphorus) (Fig 2). Where there was more available phosphorus, the uptake of the same nutrient by potato plant was high; the highest plant (tuber) phosphorus was highest at Saboti $(0.9 \%)$. There was however marginal significant difference between plant (tuber) phosphorus at Ainabkoi $(0.6 \%)$ and Lari $(0.5 \%)$. This contributed to mean "ware" tuber yields being highest at Saboti $\left(19.2 \mathrm{t} \mathrm{ha}^{-1}\right)$, average at Ainabkoi $\left(9.6 \mathrm{t} \mathrm{ha}^{-1}\right)$ and least at Lari $\left(8.8 \mathrm{tha}^{-1}\right)($ Fig 4 ; table 4 \& 5).

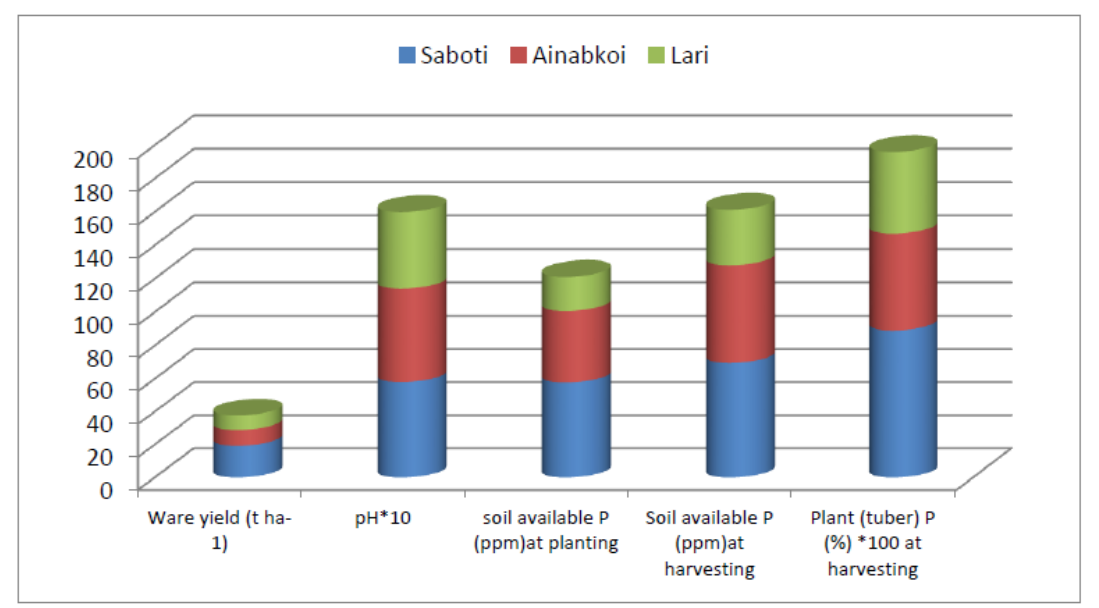

Figure 4. Comparions of "ware" yield with soil pH, soil available phosphorus and Plant (tuber) phosphorus

\section{Conclusions}

Unica had better response to phosphorus rate application than Shangi (In all the test sites and at almost all levels of phosphorus rate application, the overall mean yields of Unica were higher than Shangi's). Phosphorus positively and significantly influenced yield of "ware" potatoes in the three test sites. Highest yields of Shangi and Unica "ware" potato tubers at Saboti were realized by $120 \mathrm{~kg} \mathrm{ha}^{-1}$ and $90 \mathrm{~kg} \mathrm{ha}^{-1}$ phosphorus; at Ainabkoi highest yields of both varieties were realized by $120 \mathrm{~kg} \mathrm{ha}^{-1}$ phosphorus while at Lari highest yields of the same were realized by $90 \mathrm{~kg} \mathrm{ha}^{-1}$ and $120 \mathrm{~kg} \mathrm{ha}^{-1}$ phosphorus, respectively. In general, all the test sites required $90 \mathrm{~kg}$ $\mathrm{ha}^{-1}$ phosphorus application for production of highest "ware" tuber potato yields.

Within the "ware" potato season, there was a build-up of soil available phosphorus status. The mean tuber phosphorus was highest in the harvested tubers from Saboti. There was a strong correlation between mean available soil available phosphorus and mean plant (tuber) phosphorus. Correlation between Mean soils available phosphorus at planting and at harvesting was very strong. Higher soil $\mathrm{pH}$ in the range of (5.5 - 6.5) favoured "ware" potato yields. Many potato values chain actors particularly farmers have very limited information on the most recent varieties introduced in Kenya.

\section{Acknowledgement}

Many thanks to University of Eldoret for invaluable support, Kenyatta University (Statistics Department) for their insightful contributions, National Agricultural Research Laboratories (Kabete) and Kenya Agricultural and Livestock Research Organization (Muguga) for their support in Laboratory analysis. We appreciate Kenya Agricultural and Livestock Research Organization (Tigoni) for their wise counsel. Special thanks to Potato Pesa Project for partially funding the research project. We owe a lot of gratitude to the following agricultural officers who played a big role in this work: Mr. Wachira (Kiambu), Mr. Wasike (Trans Nzoia) and Mr. Wanyike (Uasin Gishu). We are grateful to Mr. Paul Nabu of Lari, Mr Franco Khaemba of Saboti and Mr. Sammy Biwot of 
Ainabkoi for providing test farms for the study. We appreciate the seed farms belonging to Agricultural Development Cooperation (Molo, Kenya) and Lydia Marindich for availing the seed potato tubers to plant. Many thanks to Great Mercy Development Centre for allowing their students to participate in this study; particularly during the harvesting activity, Ruth Chepkemei A. from Mount Kenya University and Grace Vugutsa from Vekaria Construction Company for editing this work. Above all, we thank the almighty God for giving us the grace that we needed in the whole process.

\section{References}

Abong'o, G. O., \& Kabira, J. N. (2013). The current status of potato value chain inKenya, 25-26 may. Trends and opportunities in the production,processing and consumption of staple food crops in Kenya-Conference. : 56-59. Hotel intercontinental, Nairobi. Retrieved from

https://profiles.uonbi.ac.ke/ookogeorge/files/potato_value_chain_abstract_for_staple_food_conf_april_2013 .docx

Agro Eco Lab. (2016). Protocal on Mehlich procedures.

Birtukan, B. (2016). Effect of nitrogen and phosphorus rates on growth, yield, yield components and quality of potato (Solanum Tuberosum L.) at Dedo, South West Ethiopia (Msc). Jimma University, Jimma, Ethiopia.

Carl, J. R., Keith, A. K., Jeffery, C. S., \& Gregory, A. P. (2014). Optimizing Phosphorus Fertilizer Management in Potato Production Potato Association of America.

CIP. (2020). International potato centre. Potato Facts and figures. Retrieved from https://cipotato.orgcropspotato

CK. (2020). CK-12 foundation 2020. Toxicity of micronutrients. Retrieved from www.ck12.org

Duroy, A. N., Aymeric, G., \& Roshani, S. (2009). Nutrition value of potato: vitamin, phytonutrient, and mineral content.

Ekelöf, J. (2007). Potato yield and tuber set as affected by phosphorus fertilization. Master project in the Horticultural Science Programme, 2, 20.

FAO. (2008). Statistics division, 2008. Rome: FAO. Retrieved from http://faostat.fao.org

FAO. (2019). Statistics division, 2019. Rome: FAO. Retrieved from http://faostat.fao.org

FAO-UNESCO. (1974). FAO-UNESCO soil map of the world, 1: 5000000 maps and data bases. Retrieved from http://www.fao.org.soil

Harova, L. V. M., \& Spejra, R. K. R. (2014). Soil analysis using Mehlich 3 extractant techniques for sample preparation. Teledyne technologies. Retrieved from http://www.teledynecetac.com/resourceSite/Application.Notes/HAM0852.pdf

Israel, Z., Ali, M., \& Solomon, T. (2012). Effect of different rates of nitrogen and phosphorus on yield and yield components of potato (Solanum Tuberosum L.) at Masha District, Southwestern Ethiopia. International Journal of Soil Science, 7, 146-156. http://dx.doi.org/10.3923/ijss.2012.146.156

Jaetzold, R., Schmidt, H., Hornetz, B., \& Shisanya, C. (2011). Farm Management Handbook of Kenya. Vol. II. Natural Conditions and Farm Management Information 2nd Edition Part B. Central Kenya. Subpart B2. Ministry of Agriculture, Nairobi, Kenya.

Jaetzold, R., \& Schmidt, H. (2009). Farm Management Handbook of Kenya. Vol. II/C Kenya. Natural Condition and Farm Management Information. Ministry of Agriculture and German Agricultural Team (GTZ), Nairobi.

Kaguongo, W. P., Gildemacher, P., Demo, P., Wagoire, W., Kinyae, P., Andrade, J., Forbes, G., Fuglie, K., \& Thiele, G. (2008). Farmer practices and adoption of improved potato varieties in Kenya and Uganda. CIP, Lima, Peru, 5, 42.

Karanja, A. M., Makokha, G. L., \& Shisanya, G. A. (June, 2014). Analysis of the key challenges facing potato farmers in Oljoro-orok Division, Kenya. https://doi.org/10.4236/as.2014.510088

KARI. (2008). Production of food (ware) potatoes. KARI information. Retrieved from www.reportlinker.com/potato

KEPHIS. (2016). KEPHIS Seed Potato Production and Certification Guidelines.

Lutaladio, B., Oscar, O., Daniel, C., \& Cain, M. (2009). Sustainable potato production guidelines for developing countries. Food and Agriculture Organization of the United Nations. 
MOA. (2011). Ministry of Agriculture, Kenya. Field crops technical hand book.

Muthoni, J. (2016). Soil fertility situation in potato producing Kenyan highlands-case of KALRO-Tigoni. International Journal of horticulture, 6(25), 1-11. https://doi.org/10.5376/ijh.2016.06.0025

NAAIP. (2014). Soil suitability for growing maize in Kenya. National Agriculture Accelerated Inputs Programme report.

NPCK. (2013). National Potatao Council of Kenya potato production manual. Books potato production manual. Retrieved from https://npck.org

NPCK (2016). National Potato council of Kenya potato variety catalogue booklet K2.

NPCK (2017). National Potato council of Kenya potato variety catalogue booklet K2.

NPCK. (2019). National Potatao Council of Kenya potato production manual. Books potato production manual. Retrieved from https://npck.org

Okalebo, J. R., Gathua, K. W., \& Woomer, P. L. (2002). Laboratory Methods of Soil and Plant Analysis. A working manual. The second edition.TSBF-CIAT and SACRED.Africa, Kenya.

Onder, S., Caliskan, M. E., Onder, D., \& Caliskan, S. (2005). Different irrigation methods and water stress effects on potato yield and yield components. Agriculture and Water Management, 73, 73-86. http://dx.doi.org/10.1016/j.agwat.2004.09.023

Shawiza, V. (2017). Status of potato farming in Kenya and its contribution to the economy.

Sophie, S. (2018). Potato variety adoption and disadoption in Kenya. Syngenta foundation for sustainable agriculture. Retrieved from http://www.hort.news

Soil Taxonomy. (1975). American Soil classification system by USDA. Natural resources conservation service, Washington DC.

Soil Survey Staff. (2014). Keys to Soil Taxonomy. 12th Edition, USDA-Natural Resources Conservation Service, Washington DC.

Spooner, D. M., McLean, K., Ramsay, G., Glenn, J., \& Bryan, G. J. (2005). A single domestication for potato based on multiple and amplified fragment length polymorphism genotyping. PNAS, 102(41), 14694-14699. https://doi.org/10.1073/pnas.0507400102

Silvar, G. (2012). The peaks and valleys of Phosphorus fixation. Michigan state University. Retrieved from_ https://www.canr.msu.edu

Tuhin, S. R., Takashi, N., \& Mohammed, H. A. (2007). Seed quality as affected by nitrogen and potassium during true potato seed production. Asian Journal of Plant Sciences, 6, 1269-1275. https://doi.org/10.3923/ajps.2007.1269.1275

Waikwa, M. (2018). New generation culture in agriculture. Retrieved from htts://farmers trend.co.ke/newpotato-varieties

WRB. (2014). World reference base for soil resources 2014. Food and Agriculture Organization of the United Nations. Retrieved from htts://www.fao.org

Yara International. (2019). Potato Crop Nutrition. Role of Phosphorus in Potato Production. Retrieved from https://www.yara.us/crop-nutrition/potato/role-of-phosphorus/

Zelalem, A., Tekalign, T., \& Nigussie, D. (2009). Response of potato (Solanum tuberosum L.) to different rates of nitrogen and phosphorus fertilization on vertisols at Debre Berhan, in the central highlands of Ethiopia. African Journal of Plant Science, 3(2), 016-024. Retrieved from http://www.academicjournals.org/AJPS

\section{Copyrights}

Copyright for this article is retained by the author(s), with first publication rights granted to the journal.

This is an open-access article distributed under the terms and conditions of the Creative Commons Attribution license (http://creativecommons.org/licenses/by/3.0/). 